\title{
Renewable Biomass Utilization: A Way Forward to Establish Sustainable Chemical and Processing Industries
}

\author{
Yadhu N. Guragain ${ }^{1,2, *}$ and Praveen V. Vadlani ${ }^{1,3}$ \\ 1 Bioprocessing and Renewable Energy Laboratory, Grain Science and Industry, Kansas State University, \\ Manhattan, KS 66506, USA; vadlani@saiverabio.com \\ 2 Process R\&D, International Flavors \& Fragrances Inc., Madison, WI 53716, USA \\ 3 Saivera Bio LLC, Puttaparthi 515134, India \\ * Correspondence: yadhu.n.guragain@iff.com or yaduait@gmail.com; Tel.: +1-608-395-2689
}

check for

updates

Citation: Guragain, Y.N.; Vadlani, P.V. Renewable Biomass Utilization: A Way Forward to Establish Sustainable Chemical and Processing Industries. Clean Technol. 2021, 3 , 243-259. https://doi.org/ 10.3390/cleantechnol3010014

Received: 19 January 2021

Accepted: 4 March 2021

Published: 17 March 2021

Publisher's Note: MDPI stays neutral with regard to jurisdictional claims in published maps and institutional affiliations.

Copyright: (c) 2021 by the authors. Licensee MDPI, Basel, Switzerland. This article is an open access article distributed under the terms and conditions of the Creative Commons Attribution (CC BY) license (https:// creativecommons.org/licenses/by/ $4.0 /)$.

\begin{abstract}
Lignocellulosic biomass feedstocks are promising alternatives to fossil fuels for meeting raw material needs of processing industries and helping transit from a linear to a circular economy and thereby meet the global sustainability criteria. The sugar platform route in the biochemical conversion process is one of the promising and extensively studied methods, which consists of four major conversion steps: pretreatment, hydrolysis, fermentation, and product purification. Each of these conversion steps has multiple challenges. Among them, the challenges associated with the pretreatment are the most significant for the overall process because this is the most expensive step in the sugar platform route and it significantly affects the efficiency of all subsequent steps on the sustainable valorization of each biomass component. However, the development of a universal pretreatment method to cater to all types of feedstock is nearly impossible due to the substantial variations in compositions and structures of biopolymers among these feedstocks. In this review, we have discussed some promising pretreatment methods, their processing and chemicals requirements, and the effect of biomass composition on deconstruction efficiencies. In addition, the global biomass resources availability and process intensification ideas for the lignocellulosic-based chemical industry have been discussed from a circularity and sustainability standpoint.
\end{abstract}

Keywords: lignocellulosic biomass; pretreatment; sustainability; process intensification; chemicals

\section{Global Biobased Products Scenario: Feedstock Availability and Sustainability}

The global pandemic and disruptions to global manufacturing hubs have severely affected the status quo of the established chemical industry. It is clearly evident that the industry will have to re-engineer, re-position and innovate to stay relevant and to retain the close to 4 trillion USD in global revenue. For this to happen, sustainability, decarbonization, process intensification and circularity concepts are to be strictly followed and implemented [1]. To challenge and augment the chemical industry, processing of renewable resources to biobased-chemicals and biofuels is the way forward provided sustainable financing and business valuation are entertained [2]. Particularly, transportation fuels and climate change are topics of keen discussion in both the political and scientific communities throughout the world. A gradual decrease in global petroleum reserves leading to their depletion in the near future requires a search for sustainable alternatives to fossil fuels. In addition, increasing conflict in most oil-producing countries has further worsened the fuels crisis, particularly for non-oil-producing countries [3]. The international energy crises in 1973 quadrupled United States (US) oil prices from USD 4.50 to USD 22.50 per barrel and caused significant damage to the US economy. This forced the US government to search for alternative sources of energy, including corn ethanol production [4]. The US is the largest fuel ethanol producer (58\% of global production), followed by Brazil (25\%), Europe (6\%), China (3\%) and Canada (2\%) [5]. In 2016, the US produced about 15 billion gallons of biofuel along with 42 million metric tons (MMT) of high protein animal feed [2]. Current 
approaches to production of bio-based fuels and chemicals using food-based feedstocks are inadequate to replace petroleum products without affecting the global food supply. Lignocellulosic biomass feedstocks are a sustainable and low-cost alternative to the current food-based feedstocks [6].

Sustainability of the lignocellulosic-based biofuels and biochemical industries should be evaluated using three criteria: economic, environmental, and social factors [2,7]. Life cycle assessment (LCA) of biofuels has been extensively studied to evaluate their sustainability; however, LCA primarily focuses on the environmental and economic impact of biofuels with limited attention toward social aspects. The functional units of LCA of the biofuels from biomass are net energy balance and greenhouse gas (GHG) emission [8]. For bioeconomy sustainability, the biorefining program and feedstock production must be designed with the participation of local and rural communities to address their societal needs [9]. The major driving factors for growing interest in lignocellulosic-based fuels and chemicals production are energy security, environmental concerns due to increasing GHG emission, economic development and job creation in rural areas [6,7].

The U.S. Department of Energy performed extensive studies on the national biomass resource availability, called the Billion-Ton Study, which was first published in 2005, and updated in 2011 and 2016. These reports are the landmark resource for US biorefinery stakeholders, which evaluated the fundamental question whether the land resources in the US can sustainably produce biomass feedstocks for biorefineries. The latest series of the report published in 2016 performed the broad assessment of biomass resources and included algae and municipal solid waste resources for the first time. It also had more detailed analysis of dedicated energy crops and transportation cost of biomass to the biorefinery. The report is in two volumes: the first volume contains economic availability of feedstocks under specified maker scenarios, cost of production, harvesting and transportation of these feedstocks; whereas the second volume contains environmental sustainability effect of select scenarios. The study estimated that at the price of USD 60/dry ton at the roadside, 1.2 and 1.5 billion dry tons of biomass will be available by 2040 under base-case and high-yield scenario, respectively $[10,11]$.

The global lignocellulosic biomass production is estimated to be around 146 billion tons per year; a small part of it is currently being used for biofuels and biochemical production [12]. Current global land use to grow biofuels feedstocks is only 25 million hectares, which is $0.19 \%$ of world's total land area [7]. The estimated global production of four major crops residues-corn stover, rice straw, wheat straw, and sorghum stover in 2011 were 1413, 1084, 1056, and 81 million tons, respectively. Forest residues were estimated at 274 million tons in 2011 but are projected to be the major feedstock for future biorefineries with estimated production of 6 billion tons per year by 2050. In addition, municipal solid waste is available in large quantities, and can also be a potential feedstock for biorefinery operations. The estimated global municipal solid waste in 2011 was 1.3 billion tons, which has expected to be 2.6 billion tons per year by 2025 [13]. Therefore, the global biomass potential indicates that the feedstock availability is not the key issue to produce enough bio-based products that can substantially replace fossil-fuel resources.

Despite the availability of large lignocellulosic biomass resources, bio-based products are yet to be commercially viable compared with petroleum-based products primarily due to expensive and inefficient bioconversion technologies [2]. In addition, the biomass feedstocks, especially agricultural residues, are seasonably available. Therefore, each biorefinery should be capable of utilizing multiple feedstocks comprising annual and perennial biomass and should have appropriate feedstock handling and storage capability for the continuous operation of the plants [14]. Therefore, process integration and intensification to develop cost effective and green biomass conversion technologies that utilizes all components of lignocellulosic biomass to produce fuels, chemical, and power is vital for the transition of the current fossil-fuel economy to a sustainable bioeconomy $[2,15]$.

The continued success of the petrochemical industry is due to their ability to effectively utilize every derivative of crude oil after cracking to produce a plethora of low-cost indus- 
trial chemicals, monomers and materials [2]. The petroleum-derived chemicals' market is less than $10 \%$ of crude oil, but significantly contributes to the overall profitability of petrochemical industries [16]. A biorefinery concept analogous to that of a petroleum refinery must be developed to utilize multiple feedstocks for the betterment of overall economics and sustainability. To complement this concept, the sustainable biorefinery should focus on high-volume and low-valued biofuels production to meet the green energy demand and low-volume and high-valued bio-based chemicals production for the economic viability of the industry [2].

\section{Conversion of Lignocellulose Biomass to Fuels and Chemicals}

Basically, there are two primary routes for the conversion of lignocellulosic biomass to biofuels and biochemicals: (1) biochemical conversion, and (2) thermochemical conversion, as shown in Figure 1. The biochemical conversion technologies utilize microorganisms or other biocatalysts to convert biomass to several biofuels and biochemicals, including bioethanol, biobutanol, 2,3-butanediol, biodiesel, and biogas [6]. Thermochemical conversion technologies utilize heat and chemical catalysts to convert biomass to valuable secondary energy/fuel sources [12,17].

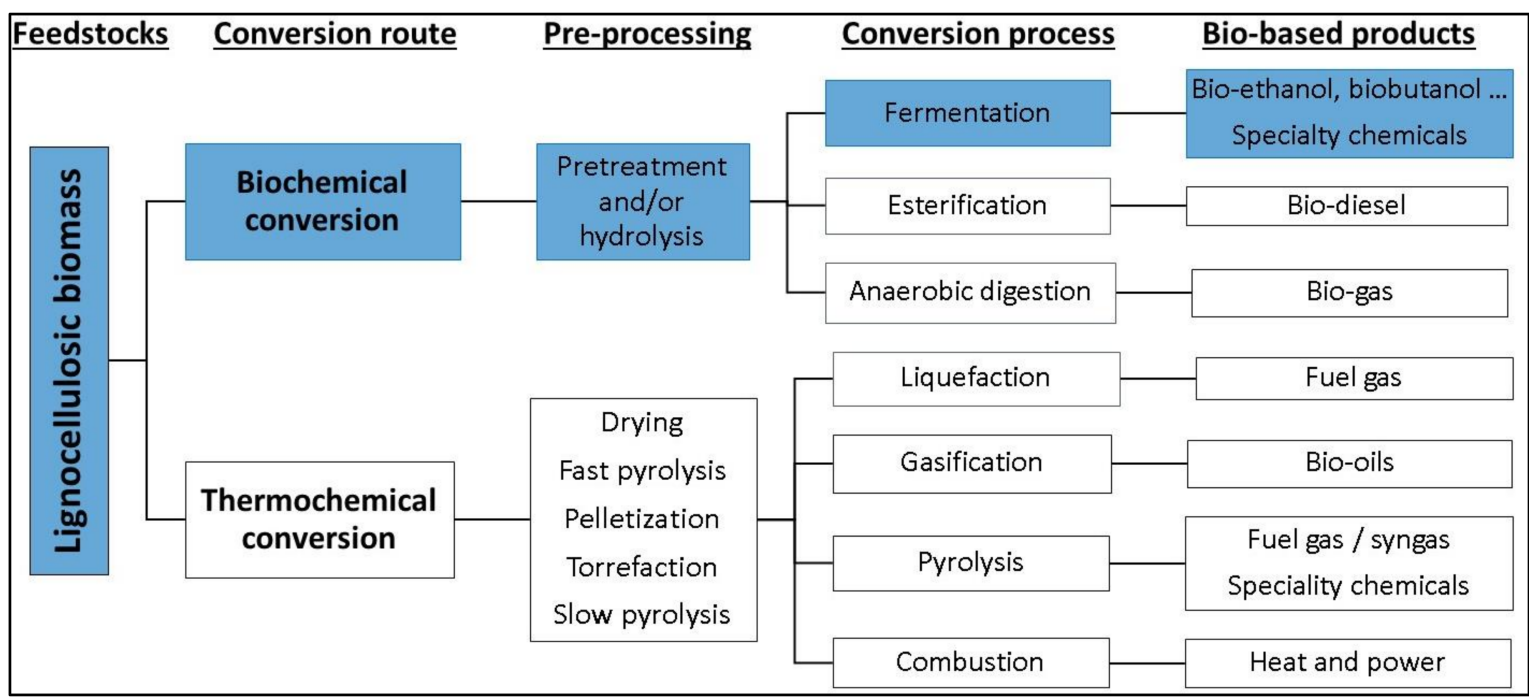

Figure 1. Conversion routes for lignocellulosic biomass feedstocks to bio-based products $[6,12,17]$.

Each biomass conversion route has many inherent strengths and weaknesses; the appropriate conversion route is determined by many factors, including feedstock types, availability of technology, need for specialized enzymes and robust microbes for conversion, and energy requirements. The highlighted path of the biochemical conversion route is the most relevant and studied process and is called the sugar platform route; this review has focused on this platform for a meaningful discussion and insights related to lignocellulosic biomass conversion.

In the sugar platform route, lignocellulosic biomass is deconstructed using appropriate pretreatment method followed by enzymatic hydrolysis to release monomer sugars from carbohydrate polymers (cellulose and hemicellulose). The released sugars are fermented to desired biofuels or biochemicals using specific microbial culture [14,18]. Integrated biorefinery comprises four major sections for the conversion of biomass to fuels and chemicals through the sugar platform route: feedstocks handling and storage, pretreatment, hydrolysis, and fermentation and product recovery, as shown in Figure 2 [19]. Several factors affect the efficiencies of each section of this biomass conversion process and each of these steps is associated with several challenges [3,20]; among them pretreatment is not only the most energy-intensive single step but also affects the efficiencies of the subsequent conversion processes [2,21-24]. 


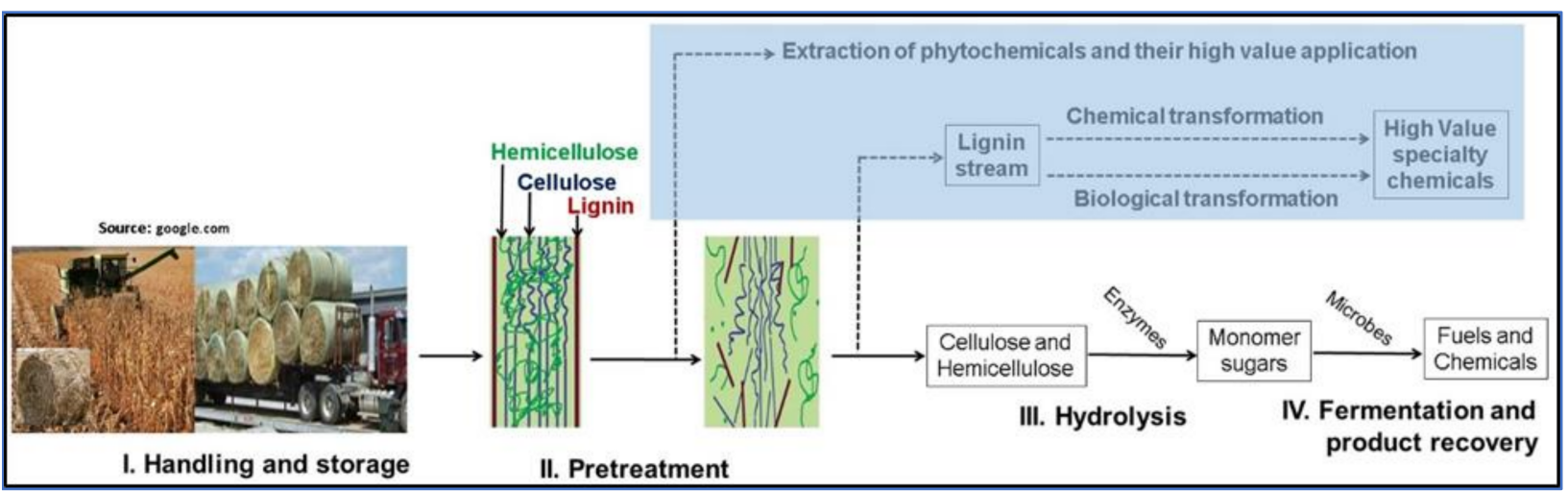

Figure 2. Integrated lignocellulosic biomass conversion through sugar platform route. The shaded portion shows the potential paths to valorize under-utilized streams of the process $[6,19,25]$.

\section{Lignocellulosic Biomass Pretreatment}

The primary objective of the pretreatment process is to deconstruct the complex biomass structure comprising lignin, hemicellulose, and cellulose so that each biopolymer can be effectively utilized to produce fuels, chemicals and power $[5,26]$. Each step of biomass processing, including pretreatment, hydrolysis and fermentation, have many challenges that need to be overcome for commercial viability of lignocellulosic-based biorefineries. Among these processes, pretreatment is considered the central unit operation, which significantly affects the effectiveness of all other subsequent steps of biomass processing [6,27]. Montague et al. [21] estimated that if dilute acid pretreatment is used before enzymatic hydrolysis, the capital investment for pretreatment is $17 \%$ of the total capital investment (USD 19 million out of USD 113 million) and incurs the highest investment of a single step for bioethanol production from corn stover. Humbird et al. [23] proposed an improved two-step acid pretreatment with some process modifications and estimated that capital investment for biomass pretreatment is around 13\% of total capital investment (USD 30 million out of USD 232 million). The lower percentage of pretreatment cost in the study by Humbird et al. [23] compared with the earlier study by Montague et al. [21] was due to an increase in capital cost for wastewater treatment. Similarly, Yang \& Wyman [22] reported that the pretreatment alone incurs $18 \%$ of total investment for cellulosic ethanol production. These studies indicated that development of a cost-effective pretreatment method is vital for lignocellulose-based biorefineries. In addition, lignocellulosic-based biorefinery currently focuses on cellulose-derived sugars; the lignin stream is combusted as boiler fuel, which is a very low-value application of the energy-rich hetero-polymer [6]. Lignin comprises $40 \%$ of lignocellulosic biomass by energy even though it is only 15 to $30 \%$ by weight [28]. Therefore, lignin valorization is critical for the sustainability of biorefining industries, which in turn is related to the appropriate pretreatment method to extract good quality biomass lignin [19].

Several biomass pretreatment methods are available, including physical, chemical, physico-chemical, and biological [29]; some of them are listed as follows:

1. Physical methods: extrusion, ball milling, wet-disc milling, microwave pretreatment.

2. Chemical methods: acid pretreatment, alkali pretreatment, organosolv pretreatment, ozonolysis pretreatment.

3. Physico-chemical methods: steam explosion, ammonia fiber explosion, liquid hot water, carbon dioxide explosion, wet oxidation.

4. Biological methods: white-rot fungi, brown-rot fungi, soft-rot fungi.

Some of the promising pretreatment processes are critically discussed below.

\subsection{Extrusion Pretreatment}

Extrusion processing is one of the promising physical pretreatment methods for deconstruction of lignocellulosic biomass [30]. It is a widely used in snack food industries 
and in this process, material is forced through a die with desired cross-section profile. When the material passes through the extruder, several unit operations, including heating, mixing and shearing, take place simultaneously resulting in physical and chemical alteration. Finally, the material experiences an abrupt expansion while exiting the die [31]. The complex networks of biopolymers in lignocellulosic biomass is disrupted during the extrusion process, thereby making the biomass susceptible for enzymatic action without the production of pretreatment-induced inhibitory compounds that are detrimental to the subsequent biomass hydrolysis and fermentation processes [32].

There are two type of extruders: single-screw extruder and twin-screw extruder, with three types of screw elements. The (a) forward screw elements-transports bulk materials through different pitches and lengths with minimum mixing and shearing effect; (b) kneading screw elements-very slowly conveys materials forward with high mixing and shearing effect through different stagger angles; and (c) reverse screw elements-pushes material backward with very high mixing and shearing effect [30]. Effective biomass pretreatment can be achieved by optimizing the appropriate screw configuration, including pitches, lengths, stagger angles, positions and spaces. A batch-type kneader with combination of twin-screw elements is suitable for biomass pretreatment at large scale because of excellent temperature control, very high grinding, mixing and shearing forces, high throughputs, and scalability [33]. In twin-screw extruders, two parallel screws with the same length are fixed on a stationary barrel. The direction of the screw is either co-rotating or counterrotating. The screw speed (in rpm) and the barrel temperature are the main factors to be optimized for a specific extruder to develop high shearing force for achieving maximum extrusion effect while using a targeted material [34].

Poor flow of lignocellulosic material during the extrusion process is one of the major challenges for pretreatment of lignocellulosic biomass. This frequently leads to burning of the substrate and even blocking of the die during extrusion [35]. This problem can be overcome by using high moisture content in the material [35,36]; adding processing aids, like starch [36]; or cellulose affinity additives, like ethylene glycol, glycerol, and dimethyl sulfoxide [37]. Alternatively, the biomass is soaked with an alkali solution (for example, sodium hydroxide) prior to feeding into an extruder to overcome the poor flow of biomass and to improve the delignification effect [38,39]. However, inconsistent results are reported in literature for the extrusion pretreatment using cellulose affinity additives. For example, Lee et al. [37] reported $62.4 \%$ cellulose conversion to glucose from Douglas fir using ethylene glycol as a cellulose affinity additive; the same additive did not help much for soybean hulls as reported by Yoo et al. [35].

Advantages:

- Easy process monitoring and control.

- No inhibitory compounds formation due to sugar degradation.

- Adaptability for process modification.

- Continuous and high throughput.

- No need for washing of pretreated biomass if extrusion is performed without chemical addition.

- Can be combined with other methods of pretreatment for better results [40].

Limitations:

- Lack of data for economic analysis.

- Energy intensive process.

- Poor flow during continuous processing leading to burning of material [35].

\subsection{Acid Pretreatment}

Acid pretreatment is the most extensively studied and widely used lignocellulosic biomass pretreatment process. The main objective of acid pretreatment process is to hydrolyze the hemicellulose fraction of the lignocellulosic biomass [41]. In addition, most of the biomass extractives are also solubilized during acid pretreatment process. The porous biomass residue will be more accessible for cellulase enzyme in the subsequent process 
to hydrolyze the cellulose fraction of the biomass [26,41,42]. Therefore, the effectiveness of this pretreatment method is usually enhanced with the increase in the proportion of hemicellulose and extractives fractions in the biomass. Our studies demonstrated that the total sugar yield during enzymatic hydrolysis of dilute acid pretreated biomass has a good positive correlation $\left(\mathrm{R}^{2}=86 \%\right)$ with the xylan content of raw biomass on extractivefree basis $[6,26]$. The acid pretreatment process can be carried out with concentrated acid or dilute acid; however, use of concentrated acid is not an attractive option due to excessive sugar degradation and formation of inhibitory compounds [41,43]. In dilute acid pretreatment process, biomass is mixed with dilute acid $(<4 \%, v / v)$ and heated at a temperature between $140{ }^{\circ} \mathrm{C}$ and $215^{\circ} \mathrm{C}$ for a time duration ranging from few seconds to several minutes [41]. Usually sulfuric acid is used; however, other organic acids, such as formic or maleic acids were also found equally effective [42]. The National Renewable Energy Laboratory recently designed a two-step dilute acid pretreatment method for corn stover to minimize sugar degradation during pretreatment [23]. In this method, biomass slurry containing $18 \mathrm{mg}$ sulfuric acid/dry g biomass is heated at $158^{\circ} \mathrm{C}$ for $5 \mathrm{~min}$ followed by second step heating at $130^{\circ} \mathrm{C}$ for $20-30$ with $4.1 \mathrm{~g}$ additional acid/dry g biomass.

Advantages:

- High reaction rate to solubilize the hemicellulose fraction of biomass thereby making the cellulose fraction accessible for cellulase enzymes [41,42].

- A method of deconstruction can be designed for biomass processing to generate separate hemicellulose hydrolyzates (after pretreatment) and cellulose hydrolyzates (after enzymatic hydrolysis).

- Cost saving for xylanase enzymes: Hemicellulose is extensively hydrolyzed during pretreatment depending upon the feedstock type and processing conditions; therefore, high-cost xylanase enzymes are not generally required for hydrolysis [27].

Limitations:

- Inhibitors, such as furfural and hydroxymethylfurfural (HMF), produced from sugar degradation requires an additional detoxification step to make the released sugars fermentable [43].

- Need expensive stainless-steel vessels due to the corrosive nature of acid [44].

- Additional cost for alkali to neutralize acid after pretreatment.

- Environmental concern due to excessive use of chemicals.

\subsection{Alkali Pretreatment}

Alkali pretreatment is another extensively studied and widely used lignocellulosic biomass pretreatment method. This process is like acid pretreatment process, but usually carried out at a lower temperature. While acid pretreatment solubilizes hemicellulose fraction of the biomass, the goal of alkali pretreatment process is to solubilize lignin fraction of the lignocellulosic biomass. Like in acid pretreatment process, alkali pretreatment process also solubilizes most of the biomass extractives. The porous biomass residue will be more accessible for enzymes in the subsequent process to hydrolyze the cellulose and hemicellulose fractions of the biomass $[6,26,42]$. Therefore, it is generally considered that the effectiveness of alkali pretreatment process is related to the total lignin content in the biomass. However, our study showed a weak negative correlation $\left(R^{2}=15 \%\right)$ between the lignin content in raw biomass on extractive-free basis and the sugars released during the hydrolysis of alkali pretreated biomass, indicating that lignin structure and the composition of different lignin monomers also significantly affect the biomass pretreatment efficiency $[6,26]$. Alkalis such as sodium hydroxide $(\mathrm{NaOH})$, potassium hydroxide $(\mathrm{KOH})$ and ammonium hydroxide $(\mathrm{NH} 4 \mathrm{OH})$ are suitable for biomass pretreatment [6,42]. $\mathrm{NaOH}$ has been extensively studied since the pretreatment results in higher delignification and deacetylation [45] and the decrease in crystallinity of cellulose due to swelling of residual biomass during pretreatment [42]. 
Advantages:

- Effective delignification [45].

- Lower sugar degradation compared to dilute acid pretreatment due to the lower processing temperature; possible to pretreat at room temperature using longer time.

- Lignin and other extractives can be separated before enzymatic hydrolysis without loss of carbohydrate; high possibility of getting reactive lignin for high value application [46]. Limitations:

- Excessive phenolic compounds due to lignin degradation, which are potential inhibitors for enzymatic hydrolysis of sugar polymers [42].

- Additional cost for hemicellulose hydrolytic enzymes in addition to cellulase enzymes [44].

- Additional cost for acid to neutralize alkali after pretreatment.

\subsection{Organosolv Pretreatment}

Organosolv is a promising biomass pretreatment method, in which biomass is mixed with a selected organic solvent, with or without additional catalyst (acid or alkali) and heated at an appropriate temperature and time duration. Various organic solvents or solvent mixtures can be used; including low boiling point solvents, such as ethanol, methanol and acetone; high boiling point solvents, such as glycerol, ethylene glycol and tetrahydrofurfuryl alcohol; and other classes of organic solvents, such as organic acids, phenols, ketones and dimethyl sulfoxide [47]. Ethanol organosolv pretreatment using acid catalyst has been widely studied and is carried out at $90{ }^{\circ} \mathrm{C}$ to $120{ }^{\circ} \mathrm{C}$ for grasses and $155^{\circ} \mathrm{C}$ to $220^{\circ} \mathrm{C}$ for woods with processing times of $25 \mathrm{~min}$ to $100 \mathrm{~min}$; ethanol concentration $25 \%$ to $74 \%$; and catalyst concentration $0.83 \%$ to $1.67 \%(v / v)$ [27]. Catalyst addition is not required if the processing temperature is high $\left(>185^{\circ} \mathrm{C}\right)$ because organic acids released from biomass act as a catalyst at that temperature [48]. Organosolv pretreatment almost completely removes hemicellulose and extensively removes lignin, thereby leaving digestible cellulose residues [47]. Studies on the change in cellulose crystallinity during organosolv pretreatment is limited. Ni and Van Heiningen [49] reported that ethanol-water organosolv pretreatment leads to swelling of cellulose, and the effect is inversely related to ethanol concentration. Cellulose crystallinity is not an important factor for the digestibility of pretreated biomass with low residual lignin content if hydrolysis is carried out for sufficiently long periods [50]; however, productivity of sugar release is decreased.

Organosolv pretreatment using high-boiling point alcohols, mostly polyhydroxy alcohols, is also gaining attention because the process can be performed at atmospheric conditions. Glycerol has been extensively used for the delignification of lignocellulosic biomass [47]. Its high boiling point $\left(290^{\circ} \mathrm{C}\right)$ favors biomass pretreatment at high temperature and atmospheric pressure; the process is called atmospheric aqueous glycerol autocatalytic organosolv pretreatment (AAGAOP) [51]. Use of low-cost crude glycerol, a major byproduct of oleochemical industries, for biomass pretreatment is considered an attractive economic route for biofuels and biochemicals production [52]. Oleochemical industries produce crude glycerol at around $10 \%$ of total biodiesel production. High value application of crude glycerol for food, pharmaceutical and cosmetic use is economically unfeasible due to the expensive purification process [51]. The rapid growth in global biodiesel production [53] indicated that crude glycerol will be available even in larger quantities at lower cost in the future. However, recycling of glycerol is challenging and energy intensive.

One of the major drawbacks of organosolv pretreatment is loss of hemicellulose in the lignin stream, which is hard to recover as fermentable sugars due to presence of several inhibitory compounds, such as phenolics. For the separation of all three major biopolymers (cellulose, hemicellulose and lignin) into separate streams, Hongzhang \& Liying [54] proposed a combination of steam explosion and ethanol organosolv pretreatment. In this method, the biomass was first pretreated by steam explosion to hydrolyze hemicellulose, followed by ethanol organosolv pretreatment to extract lignin. The residual cellulose is 
easily hydrolyzed using cellulase enzymes to monomer sugars. However, use of multiple steps results in the increase in operating and capital costs. Diner \& Fan [55] developed a single step alkaline organosolv pretreatment method in which various amounts of aqueous ammonia ( $2 \%$ to $20 \%(w / w)$ of biomass) was added to the biomass slurry in organic solvents and heated at desired temperature and time duration. This process led to extensive removal of lignin without significant loss of hemicellulose. The lignin-free carbohydrate polymers (cellulose and hemicellulose) were effectively hydrolyzed using enzymes.

Advantages:

- Extracted lignin is relatively of high purity, low molecular weight and sulfur free making it possible for the high value application of lignin [41,47].

- All three biopolymers—cellulose, hemicellulose and lignin-can be separated into different streams [48].

- It can be combined with other pretreatment processes for effective biomass hydrolysis. Limitations:

- High cost of solvent: Recycling process is also energy intensive [42]. Additional solvent is required to avoid lignin precipitation due to washing with water [47].

- Formation of inhibitory compounds, such as furfural and HMF, due to sugar degradation when acid catalyst is used [41].

- Residual solvent will be inhibitory for enzymatic hydrolysis and fermentative organisms.

- Environmental and health concerns due to the use of volatile organic liquids at high temperature [41].

\subsection{Ionic Liquid Pretreatment}

This is a relatively new approach for biomass pretreatment, in which the whole biomass is dissolved in a selected ionic liquid and the carbohydrate polymers are precipitated by adding appropriate anti-solvents; thereby, separating lignin and carbohydrates. Generally, water is used as anti-solvent, but methanol and ethanol can also be used. The regenerated cellulose will have reduced crystallinity and hence will be more easily digestible [3]. Ionic liquids are likely to form hydrogen bonds with cellulose due to the presences of anions, such as chloride, acetate, formate, or alkylphosphonate, at higher temperatures leading to dissolution of cellulose [56]. During the regeneration process, the water (anti-solvent) competes with the ionic liquids to form hydrogen-bonds with cellulose, leading to decrease in the solubility of cellulose in the ionic liquids; ultimately resulting in precipitation [57]. The solvent properties of the ionic liquid can be adjusted by changing desired cation and/or anion [58,59].

Advantages:

- $\quad$ Ionic liquids, considered as green solvent, are stable up to $300{ }^{\circ} \mathrm{C}$; have extremely low volatility with minimum environmental impact [3].

- Possible to separate each of the biopolymers-cellulose, hemicellulose and lignin.

- $\quad$ Ionic liquid with desirable properties can be synthesized.

Limitations:

- Cost of ionic liquids are still very high.

- Many ionic liquids are toxic to the hydrolytic enzymes and the fermenting organisms [60].

- Cost of solvent recovery is tedious and expensive.

- Difficult to handle the viscous biomass slurry with ionic liquid during pretreatment at temperature beyond $150{ }^{\circ} \mathrm{C}$ [52].

\subsection{Steam Explosion Pretreatment}

Steam explosion pretreatment is a widely studied physiochemical pretreatment process. In this process, the ground and preconditioned biomass is treated with saturated steam at high temperature $\left(160-290{ }^{\circ} \mathrm{C}\right)$ and high pressure $(0.7$ and $4.8 \mathrm{MPa})$ for a few seconds to several minutes before the pressure is explosively released $[27,41]$. Hemicellulose is extensively hydrolyzed due to the formation of acetic acid from the released acetyl 
groups present in the biomass polymers; additionally, water also acts as an acid at high temperature and further helps hemicellulose hydrolysis-a process also called autohydrolysis [25]. The chemical effect of hemicellulose hydrolysis along with the physical benefit of explosive pressure decompression leads to redistribution of lignin polymers and its partial removal from the material [42]. This method is more effective in hardwood and herbaceous biomass but needs addition of acid catalyst for effective pretreatment of softwood due to the presence of lower amount of acetyl groups in softwood hemicellulose [41].

Advantages:

- No use of chemicals and hence no recycling and environmental costs.

- Relatively less dilution of released hemicellulose.

- High particle size biomass can be used, leading to significant energy savings. Size reduction accounts to around one third of the entire pretreatment process [61].

Limitations:

- Incomplete de-construction of lignin-carbohydrate complex may lead to condensation and precipitation of soluble lignin; thereby resulting in reduced biomass hydrolysis efficiency [62].

- High temperature (around $270{ }^{\circ} \mathrm{C}$ ) is the best to enhance cellulose digestibility; however, this leads to the formation of inhibitory compounds-furfural and HMF [41,63].

- Weak acids and phenolic compounds, such as acetic, formic and levulinic acids, generated during this process are inhibitory for subsequent enzymatic hydrolysis and fermentation [42].

\subsection{Ammonia Fiber Explosion Pretreatment (AFEX)}

The AFEX method is an alkaline physicochemical pretreatment process. Its processing method is similar to that of steam explosion but operates at lower temperature. In this process, the biomass is mixed with liquid anhydrous ammonia ( 0.3 to $2 \mathrm{~kg} / \mathrm{kg}$ dry biomass); cooked at $60-90{ }^{\circ} \mathrm{C}$ and at pressure above $3 \mathrm{Mpa}$ for $10-60 \mathrm{~min}$. The optimum ratio of ammonia to biomass, and cooking temperature, pressure and time depends on the type of lignocellulosic biomass materials. After cooking at desired conditions, the vent valve is rapidly opened to release pressure explosively $[27,64]$. The sudden pressure release results in a rapid expansion of the ammonia gas leading to swelling and physical disruption of biopolymers as well as reduction of cellulose crystallinity. The volatile ammonia gas is recovered for reuse and the dried solid biomass is ready for enzymatic hydrolysis [65]. The AFEX method is very effective for herbaceous crops and agricultural residues, but relatively less effective for woody biomass. AFEX is also considered as a feasible method for the pretreatment of herbaceous biomass to extract protein for animal feed along with sugar generation for biofuels production [66].

Advantages:

- No formation of inhibitory compounds like furfural and HMF from sugar degradation due to low temperature operation $[42,64]$.

- High selectivity for delignification.

- $\quad$ Easy for recycling due to volatile nature of ammonia; 99\% ammonia recovery is possible.

- Residual ammonia can serve as a nitrogen source for the organisms during fermentation. Limitations:

- $\quad$ Excess water requirement because the phenolic fragments of lignins must be washed to avoid inhibition during enzymatic hydrolysis and fermentation [64].

- Ammonia recycling is very costly for commercial scale processing [25].

- Inefficient for high lignin content biomass, such as softwood and newspapers waste.

- Environmental concern due to the use of volatile chemicals.

\subsection{Liquid Hot Water (LHW) Pretreatment}

Different terminologies are used in literature to describe this process, including solvolysis, hydrothermolysis, aqueous fractionation, and aquasolv [41]. This process is comparable 
with dilute acid pretreatment without using acid [64]. In this process, biomass slurry in water is cooked at elevated temperature $\left(160-240^{\circ} \mathrm{C}\right)$ for various time periods, depending on biomass type, to solubilize hemicellulose fraction of biomass leading to cellulose enriched portion [41,42]. Mechanism of action is like steam explosion for hemicellulose solubilization. Sometimes potassium hydroxide $(\mathrm{KOH})$ is used to control $\mathrm{pH}$ from 5 to 7 during LHW pretreatment and to minimize inhibitory compound formation due to sugar degradation [25].

Advantages:

- No use of additional chemicals.

- No need to use expensive and corrosive-resistant materials for pretreatment reactors.

- Relatively large size particles can be used leading to energy saving, which is required for size reduction of biomass to fine particles.

- Possible to recover separately the cellulose and hemicellulose streams.

- Minimum formation of inhibitory compounds.

Limitations:

- The xylose stream is of very low concentration and hence needs an additional costintensive evaporation of water operation to get appropriate sugar concentration for fermentation.

- High cost since high pretreatment temperature is required.

- Not suitable for biomass with high-lignin content.

\subsection{Biological Pretreatment}

Biological pretreatment involves use of microorganisms to degrade biomass lignin and make carbohydrate polymers susceptible for enzymatic hydrolysis. Among various organisms capable of producing enzymes to degrade lignin and carbohydrate polymers of biomass, white-rot, brown-rot, and soft-rot fungi are important [67]. The white-rot fungi being the most effective for biomass pretreatment because of their enzymatic efficiency and economy. The brown-rot fungi degrade cellulose, whereas white-rot and soft-rot fungi degrade both lignin and cellulose [41]. The ligninolytic enzyme system of white rot fungi primarily consists of lignin peroxidase ( $\mathrm{LiP})$, manganese peroxidase $(\mathrm{MnP})$ and laccase [68]. LiP and $\mathrm{MnP}$ are heme containing glycoproteins and laccase is a multicopper oxidase having four copper ions per enzyme molecule as metal clusters [69]. The commonly used white rot fungi for lignin-degradation is Phynerochaete chrysosporium, which produces multiple isoenzymes of lignin peroxidase and manganese peroxidase. Many other white rot fungi produce laccase in addition to lignin and manganese peroxidase in varying combinations. Based on enzyme production patterns, the white rot fungi could be categorized into three groups:

* Lignin-manganese peroxidase group-P. chrysosporium and Phlebia radiate.

- Manganese peroxidase-laccase group-Dichomitus squalens and Rigidoporus lignosus.

* Lignin peroxidase-laccase group-Phlebia ochraceofulva and Junghuhnia separabilima [70].

Advantages:

- No inhibitory compounds are produced.

- The process is environmentally friendly.

Limitations:

- Very slow process; residence time is usually between 10 to 14 days [41].

- Large space is required to perform the process.

- Strict temperature control is required, leading to increased processing cost.

- Cellulose crystallinity could not be reduced [67]. 


\section{Variation of Composition and Structure among Biomass and Their Effect on Pretreatment Process}

Lignocellulosic biomass feedstocks have substantial variation in compositions of biopolymers, which significantly affect the effectiveness of the pretreatment process. We analyzed four grasses: switchgrass, sorghum stalk, brown midrib (bmr) sorghum stalk; corn stover; hardwood (poplar); and softwood (Douglas fir) feedstocks in our studies [6,14,24,26]. As shown in Figure 3, the composition of biomass not only varied among grasses, both hardwood and softwood, but also within different grasses [6]. Increased xylan and extractive content in the feedstock improve the pretreatment efficiency, whereas the opposite effect is found in feedstocks having high lignin content [26].

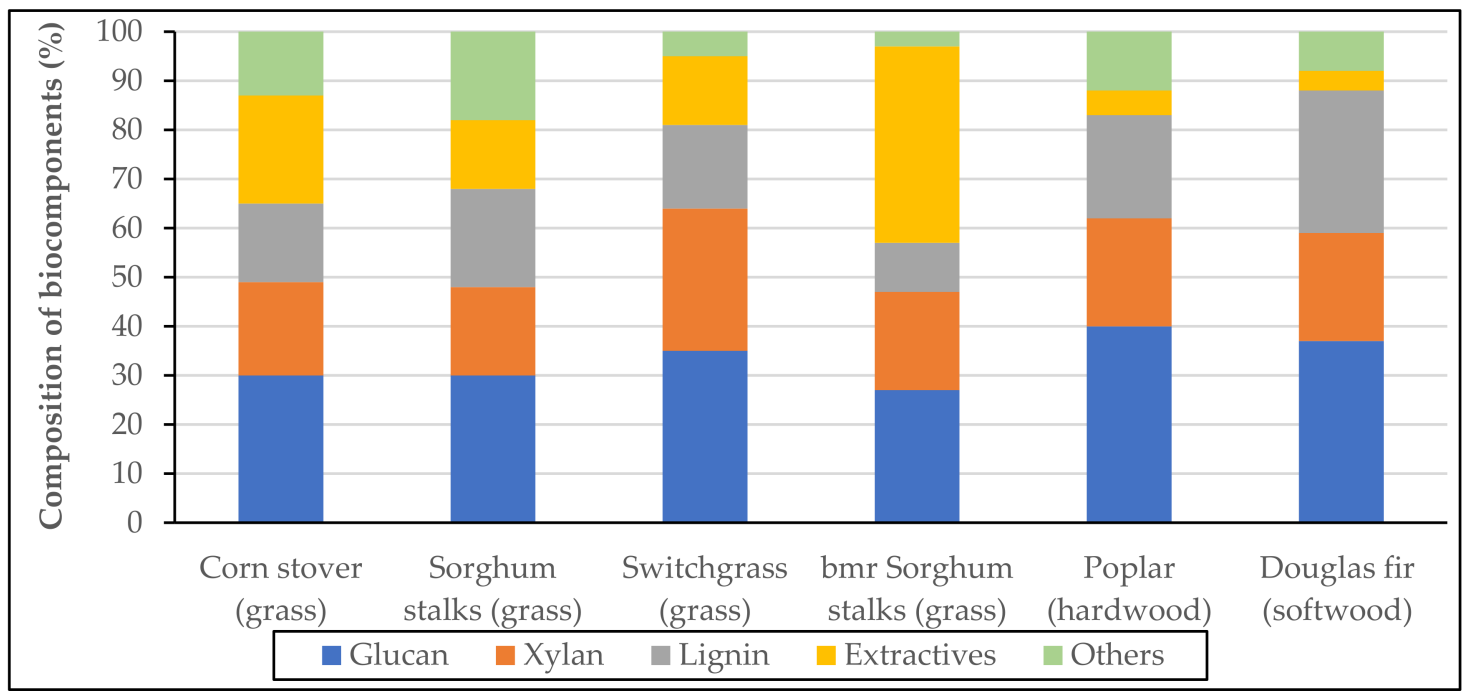

Figure 3. Composition of different biomass feedstocks. Glucan, Xylan, total lignin and total extractives were determined by following the protocols of NREL/TP-510-42618 and NREL/TP-510-42619 [6,71,72].

In addition to gross composition of each biopolymer, the structure of biopolymers, especially lignin, significantly affected the pretreatment efficiency [26]. Lignin is a heterogenous polyphenolic polymer usually made up of three types of monomers, including syringyl (S), guaiacyl $(\mathrm{G})$ and $p$-hydroxyphenyl $(\mathrm{H})$. In addition, a considerable amount of $p$-coumarates and ferulate monomers are present in the lignin of grasses as shown in Figure 4 [73]. The $p$-coumarates, ferulate and syringyl monomers are more acylated compared with other monomers $[73,74]$. These monomer units are linked together by carbon-carbon, ether or ester linkages [75]. The ether or ester linkages are more readily cleaved than carbon-carbon linages; therefore, the biomass feedstocks containing lignin with higher amount of ether or ester linkage have better pretreatment efficiency in most of the processes than lignin with higher amount of carbon-carbon linkages. Similarly, biomass digestibility increased with increasing S/G ratio, $p$-coumarates and ferulate content, and proportion of acylated lignin. In general, grasses are more digestible than woody biomass because grass lignin contains a significant amount of $p$-coumarates and ferulate monomers and thereby higher proportion of ether and ester linkages than carbon-carbon linkages. The hardwood is more digestible than softwood because of the higher S/G ratio in hardwood lignin than in softwood lignin $[24,26,75]$. 


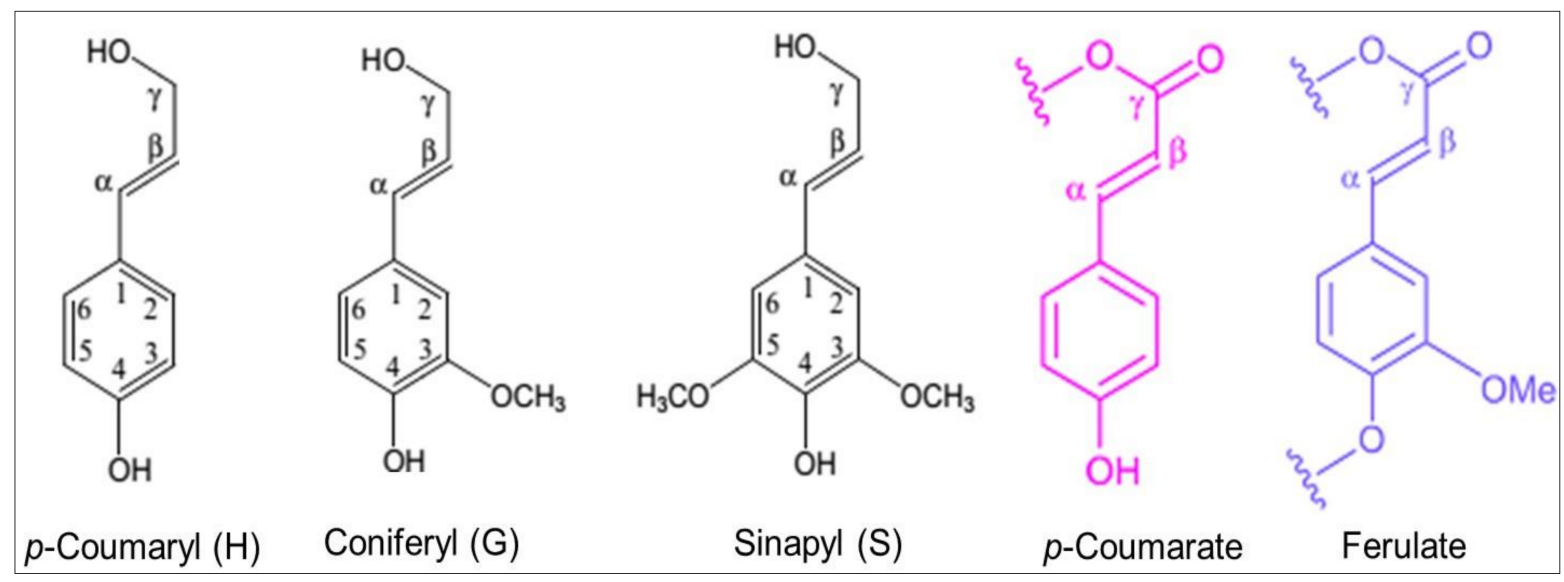

Figure 4. Lignin monomer units [75].

\section{Toward a Sustainable Lignocellulosic-Based Chemical Industry}

The global chemical industry must deviate from the existing linear economic model and follow the circular economy to meet the required sustainability and climate change goals [2]. In general, sustainable manufacturing has recently gained increasing attention to concurrently pursue economic growth, environmental protection, and societal wellbeing using closed-loop material flow by adopting 6Rs principle-Reduce, Reuse, Recycle, Recover, Redesign and Remanufacture [76,77]. Lignocellulosic biomass feedstocks are considered a promising sustainable alternative for the petroleum-based processing industries to meet their current and future raw material needs to transit to the new sustainable economy without significantly affecting global food supply. However, the bio-based industry is at an early stage and for them to compete with the matured and depreciated chemical industry is an uphill task and will require a different mindset based on sustainable business models [2]. As enumerated in this review, pretreatment of renewable biomass is a critical unit operation and is both energy and capital intensive [20]. Efforts have been made to consolidate the various steps involved in the biomass to bioproducts value-chain; however, due to different operating regimes and concomitant equipment specifications for each processing step, the consolidation has been unsuccessful. Process intensification is the sustainable path for the biorefineries, including hybridization of unit operation, new operating modes of production, and microengineering and microtechnology [1,77]. Some of the promising research initiatives for the process intensification for lignocellulosic biomass conversion include waste heat integration [78,79], microbial strain improvement for the efficient utilization of biomass-derived sugars [80], development of microbial consortia to integrate enzyme production, saccharification and fermentation in a single reactor [81], enzyme recycling and high dry matter operation to generate highly concentrated sugar streams $[26,80]$, and combination of two or more pretreatment methods for efficient biomass deconstruction [82]. Design of appropriate process intensification requires considerable amount of time and efforts depending upon the process to be intensified as well as available technologies for the process. Consequently, an appropriate process intensification methodology is required. Gourdon et al. [83] has proposed a methodology based on two-blocks, in which first block focuses on equipment qualification and technology selection, whereas second block focuses on the quality data acquisition for the proposed processes. The knowledge acquired from these initial steps will be followed by simulation, optimization, process design and equipment selection. Finally, the proposed process is validated at pilot-scale for the proof-of concept prior to dissemination of the intensified process.

In addition, lignocellulosic-based biorefinery currently focuses on cellulose-derived sugars, and the lignin stream is combusted as boiler fuel, which is a very low-value application of the energy-rich biopolymer. Lignin comprises around $40 \%$ of lignocellulosic biomass by energy even though it is only 15 to $30 \%$ by weight [28]. In addition, lignin comprises of phenolics, which could be a feedstock to make benign aromatic and specialty chemicals. 
The major roadblock for lignin valorization is not only efficient conversion of aromatics to targeted end-products but also effective fractionation of lignin and depolymerization of the sturdy polymer into homogeneous aromatic monomers [84]. Therefore, lignin valorization cannot be an independent process using the waste lignin stream from biorefinery; rather, upstream processes must be tailored with the lignin valorization research to generate a good quality lignin stream for its high-value application [19,84]. Similar approaches should be taken to produce high-value products from other components of biomass, including extractives and hemicellulose [6].

We provide a schematic in Figure 5 as an example of a promising biorefinery concept to produce high-value products from each biomass component coupled with a heatintegration approach to reduce the cost of the energy-intensive biomass pretreatment process. The proposed process has three sequential pretreatment methods at various conditions prior to the enzymatic hydrolysis of the pretreated biomass. The combination of the pretreatment methods and severity of each method depend on the biomass type and availability of resources for biomass deconstruction. The proposed conditions in each pretreatment method in this schematic are appropriate for agriculture residues with high extractives such as $b m r$ sorghum. The extractives are non-structural components of biomass, including non-structural sugars, nitrogenous materials, chlorophyll, waxes, and other phytochemicals [6,72]. From a biomass pretreatment perspective, process intensification governs energy and chemicals minimization and optimum use of high-cost stainless steel vessels for multiple processes. For example, in Figure 5, the multiple pretreatment processes can be consolidated with one equipment usage with appropriate material flow and heat exchangers network to enhance intensification. Further, if clean sugars and other product streams are generated as a consequence of an efficient pretreatment process, extractive fermentation step can be envisioned with appropriate residual water recycling. The primary drawback of ligno-cellulosic based chemical industry is the hauling of the whole biomass to the processing plant whereas all they need is a clean biomass-derived sugar stream for fermentation/bioprocessing. This hauling needlessly adds more processing steps and generation of waste/under-valued streams at biorefineries. The best way forward is to complete the biomass logistics and proposed pretreatment/sugar hydrolysis steps (Figure 5) at a consolidated biomass feedstocks facility and pump/ship the sugar and other value-added streams to an economy of scale chemical industry. This way, the reuse of biomass residues and recycling of process water in agricultural fields are enhanced. Fermentation products, such as monomers and building block chemicals, are usually biodegradable and the possibility of remanufacturing them to other materials is feasible $[14,25,85-87]$. In other words, integrated bio-based chemical industry has greater potential to realize circularity and sustainability needs of the society.

\section{Conclusions}

Development of efficient and economically viable pretreatment methods and thereby valorization of each component of biomass, including extractives, cellulose, hemicellulose and lignin is vital for the sustainable biorefinery. However, the development of a single pretreatment method for all types of feedstocks is almost impossible due to the substantial variation in composition of these biomass feedstocks and the mechanism of deconstruction of the complex biomass structure. Each pretreatment method is associated with its own strengths and limitations, which in turn depend on composition and structure of biomass. Therefore, a combination of two or more pretreatment methods with efficient energyintegration would be a more effective option to develop sustainable lignocellulosic-based chemical industry. In addition, novel process intensification methods should also be developed and implemented for all steps of biomass conversion processes, including pretreatment, hydrolysis, fermentation and product recovery to envision a circular and sustainable bioeconomy. 


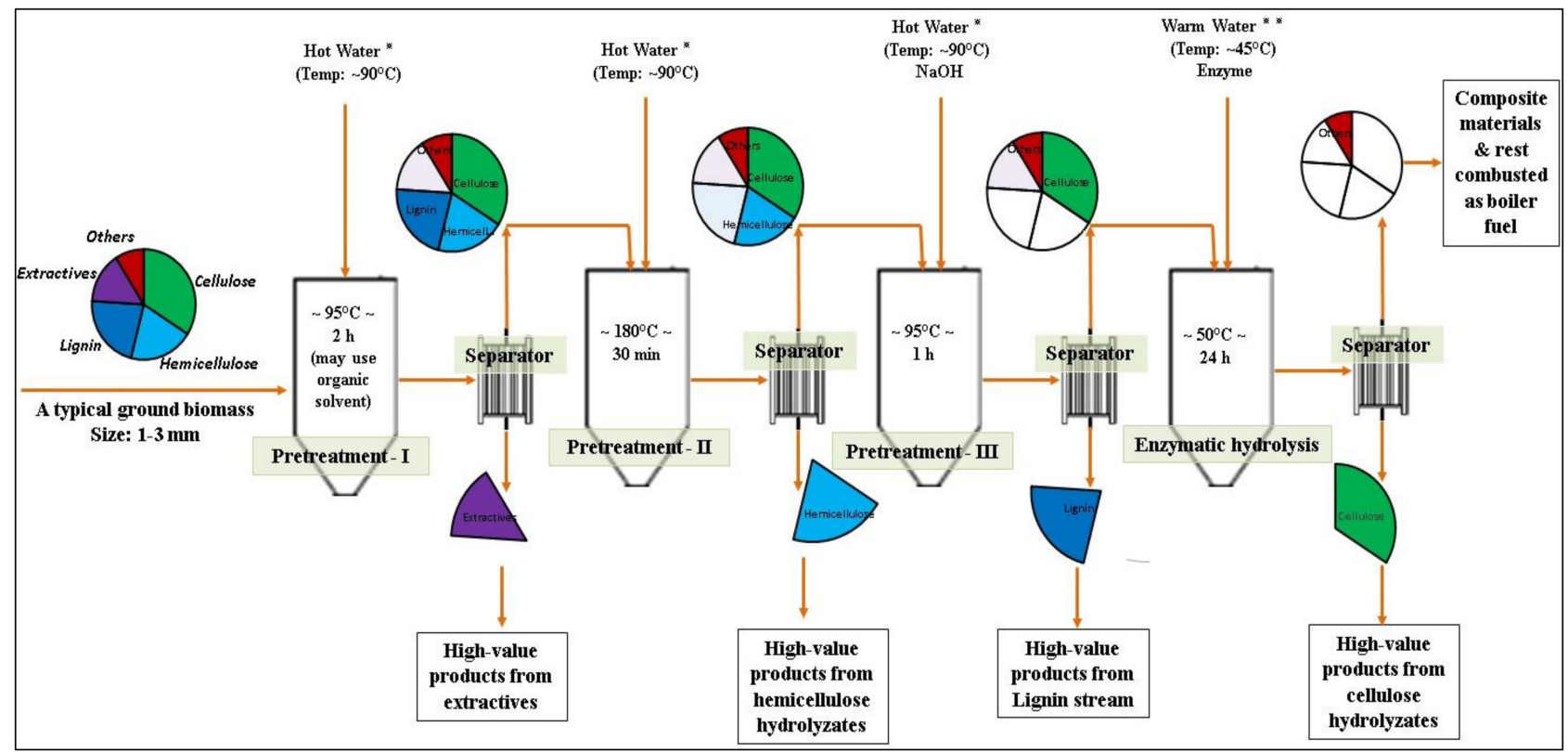

Figure 5. Schematic of an integrated biorefinery using a combination of multiple pretreatment methods followed by a secondary enzyme process to generate various streams and thereby valorize each component of lignocellulosic biomass. The processing conditions proposed in the schematic may be applicable for agriculture residues with high extractives such as bmr sorghum; however, exact conditions should be optimized for each type of biomass feedstocks [25,85]. ${ }^{*}$ Hot water around $90{ }^{\circ} \mathrm{C}$ is obtained from heat-exchanging with the biomass slurry after liquid-hot-water pretreatment at around $180{ }^{\circ} \mathrm{C}$.* Warm water around $45^{\circ} \mathrm{C}$ is obtained from heat-exchanging with the biomass slurry after alkali pretreatment at $95^{\circ} \mathrm{C}$.

Author Contributions: Conceptualization, Y.N.G. and P.V.V.; methodology, Y.N.G.; formal analysis, Y.N.G.; investigation, Y.N.G.; writing — original draft preparation, Y.N.G.; writing-review and editing, Y.N.G. and P.V.V.; visualization, Y.N.G. and P.V.V.; supervision, P.V.V.; project administration, P.V.V.; funding acquisition, P.V.V. All authors have read and agreed to the published version of the manuscript.

Funding: This work was funded by the Small Business Innovation Research (SBIR), Department of Navy; grant number: N68335-13-C-0174; and the Biomass Research and Development Initiative Competitive Grants Program (BRDI), grant number: 2012-10008-20263.

Institutional Review Board Statement: Not applicable.

Informed Consent Statement: Not applicable.

Acknowledgments: Author P.V.V. thanks the Lortscher Endowment for its support to his research program. The authors are grateful to Novozymes Inc. for the donation of the enzymes; Edenspace Inc., Manhattan, Kansas, for providing the poplar sample and Michael Wolcott, Washington State University, Pullman, Washington for the Douglas fir sample. The authors express their gratitude to Kurt Fenster, Technical Guardian, Process R\&D, Fermentation Live, International Flavors \& Fragrances Inc., for thoroughly reviewing and editing the manuscript, and Manoj Kumar Pulivarthi, Kansas State University, for his help in getting us literature materials.

Conflicts of Interest: The authors declare that they have no conflict of interest.

\section{References}

1. Charpentier, J.-C. In the frame of globalization and sustainability, process intensification, a path to the future of chemical and process engineering (molecules into money). Chem. Eng. J. 2007, 134, 84-92. [CrossRef]

2. Vadlani, P.V. Financing strategies for sustainable bioenergy and the commodity chemicals industry. In Green Energy to Sustainability: Strategies for Global Industries, 1st ed.; Vertès, A.A., Qureshi, N., Blaschek, H.P., Yukawa, H., Eds.; John Wiley and Sons Ltd.: Hoboken, NJ, USA, 2020; pp. 569-586.

3. Mousdale, D.M. Biofuels: Biotechnology, Chemistry, and Sustainable Development; CRC press, Taylor \& Francis Group: New York, NY, USA, 2008.

4. Klein-Marcuschamer, D.; Blanch, H.W. Renewable fuels from biomass: Technical hurdles and economic assessment of biological routes. AIChE J. 2015, 61, 2689-2701. [CrossRef] 
5. Guragain, Y.N.; Probst, K.V.; Vadlani, P.V. Fuel alcohol production. In Encyclopedia of Food Grain; Corke, H., Faubion, J., Seethraman, K., Wrigley, C., Eds.; Elsevier: Oxford, UK, 2016; pp. 405-414.

6. Guragain, Y.N. Sustainable bioprocessing of various biomass feedstocks: 2,3-butanediol production using novel pretreatment and fermentation. Ph.D. Thesis, Kansas State University, Manhattan, KS, USA, 2015.

7. Ladanai, S.; Vinterbäck, J. Global Potential of Sustainable Biomass for Energy; SLU Report 013; Department of Energy and Technology: Stockholm, Sweden, 2009.

8. Bonin, C.; Lal, R. Bioethanol Potentials and Life-Cycle Assessments of Biofuel Feedstocks. Crit. Rev. Plant Sci. 2012, 31, 271-289. [CrossRef]

9. Nanda, S.; Azargohar, R.; Dalai, A.K.; Kozinski, J.A. An assessment on the sustainability of lignocellulosic biomass for biore-fining. Renew. Sust. Energy Rev. 2015, 50, 925-941. [CrossRef]

10. Langholtz, M.H.; Stokes, B.J.; Eaton, L.M. 2016 Billion-Ton Report: Advancing Domestic Resources for a Thriving Bioeconomy, Volume 1: Economic Availability of Feedstocks; ORNL/TM-2016/160; Oak Ridge National Laboratory: Oak Ridge, TN, USA, 2016; p. 448. [CrossRef]

11. U.S. Department of Energy. 2016 Billion-Ton Report: Advancing Domestic Resources for a Thriving Bioeconomy, Volume 2: Environmental Sustainability Effects of Select Scenarios from Volume 1; ORNL/TM-2016/727; Efroymson, R.A., Langholtz, M.H., Johnson, K.E., Stokes, B.J., Eds.; Oak Ridge National Laboratory: Oak Ridge, TN, USA, 2017; p. 640.

12. Chew, J.; Doshi, V. Recent advances in biomass pretreatment-Torrefaction fundamentals and technology. Renew. Sustain. Energy Rev. 2011, 15, 4212-4222. [CrossRef]

13. Kurian, J.K.; Nair, G.R.; Hussain, A.; Raghavan, G.V. Feedstocks, logistics and pre-treatment processes for sustainable lignocellulosic biorefineries: A comprehensive review. Renew. Sustain. Energy Rev. 2013, 25, 205-219. [CrossRef]

14. Guragain, Y.N.; Wilson, J.; Staggenborg, S.; McKinney, L.; Wang, N.; Vadlani, P.V. Evaluation of pelleting as a pre-processing step for effective biomass deconstruction and fermentation. Biochem. Eng. J. 2013, 77, 198-207. [CrossRef]

15. Lopes, M.S.G. Engineering biological systems toward a sustainable bioeconomy. J. Ind. Microbiol. Biotechnol. 2015, 42, 813-838. [CrossRef] [PubMed]

16. Bozell, J.J.; Astner, A.; Baker, D.; Biannic, B.; Cedeno, D.; Elder, T.; Hosseinaei, O.; Delbeck, L.; Kim, J.-W.; O’Lenick, C.J.; et al. Integrating separation and conversion-Conversion of biorefinery process streams to biobased chemicals and fuels. BioEnergy Res. 2014, 7, 856-866. [CrossRef]

17. Menon, V.; Rao, M. Trends in bioconversion of lignocellulose: Biofuels, platform chemicals and biorefinery concept. Prog. Energy Combust. Sci. 2012, 38, 522-550. [CrossRef]

18. Dale, B.E.; Ong, R.G. Energy, wealth, and human development: Why and how biomass pretreatment research must improve. Biotechnol. Prog. 2012, 28, 893-898. [CrossRef]

19. Ragauskas, A.J.; Beckham, G.T.; Biddy, M.J.; Chandra, R.; Chen, F.; Davis, M.F.; Davison, B.H.; Dixon, R.A.; Gilna, P.; Keller, M.; et al. Lignin valorization: Improving lignin processing in the biorefinery. Science 2014, 344, 1246843. [CrossRef]

20. Kucharska, K.; Hołowacz, I.; Konopacka-Łyskawa, D.; Rybarczyk, P.; Kamiński, M. Key issues in modeling and optimization of lignocellulosic biomass fermentative conversion to gaseous biofuels. Renew. Energy 2018, 129, 384-408. [CrossRef]

21. Montague, L.; Slayton, A.; Lukas, J. Lignocellulosic Biomass to Ethanol Process Design and Economics Utilizing Co-Current Dilute Acid Prehydrolysis and Enzymatic Hydrolysis for Corn Stover; NREL/TP-510-32438; National Renewable Energy La-boratory: Golden, CO, USA, 2002.

22. Yang, B.; Wyman, C.E. Pretreatment: The key to unlocking low-cost cellulosic ethanol. Biofuels Bioprod. Biorefining 2008, 2, 26-40. [CrossRef]

23. Humbird, D.; Davis, R.; Tao, L.; Kinchin, C.; Hsu, D.; Aden, A. Process Design and Economics for Biochemical Conversion of Lignocellulosic Biomass to Ethanol: Dilute-Acid Pretreatment and Enzymatic Hydrolysis of Corn Stover; Technical Report NREL/TP5100-47764; National Renewable Energy Lab. (NREL): Golden, CO, USA, 2011.

24. Guragain, Y.N.; Bastola, K.P.; Madl, R.L.; Vadlani, P.V. Novel biomass pretreatment using alkaline organic solvents: A green approach for biomass fractionation and 2,3-butanediol production. BioEnergy Res. 2016, 9, 643-655. [CrossRef]

25. Mosier, N.; Wyman, C.; Dale, B.; Elander, R.; Lee, Y.; Holtzapple, M.; Ladisch, M. Features of promising technologies for pre-treatment of lignocellulosic biomass. Bioresour. Technol. 2005, 96, 673-686. [CrossRef]

26. Guragain, Y.N.; Wang, D.; Vadlani, P.V. Appropriate biorefining strategies for multiple feedstocks: Critical evaluation for pre-treatment methods, and hydrolysis with high solid loading. Renew. Energy 2016, 96, 832-842. [CrossRef]

27. Sousa, L.C.; Chundawat, S.P.; Balan, V.; Dale, B.E. Cradle-to-grave'assessment of existing lignocellulose pretreatment technologies. Curr. Opin. Biotech. 2009, 20, 339-347. [CrossRef] [PubMed]

28. Laskar, D.D.; Yang, B.; Wang, H.; Lee, J. Pathways for biomass-derived lignin to hydrocarbon fuels. Biofuels Bioprod. Biorefining 2013, 7, 602-626. [CrossRef]

29. Mood, S.H.; Golfeshan, A.H.; Tabatabaei, M.; Jouzani, G.S.; Najafi, G.H.; Gholami, M.; Ardjmand, M. Lignocellulosic biomass to bioethanol, a comprehensive review with a focus on pretreatment. Renew. Sustain. Energy Rev. 2013, 27, 77-93. [CrossRef]

30. Zheng, J.; Rehmann, L. extrusion pretreatment of lignocellulosic biomass: A review. Int. J. Mol. Sci. 2014, 15, 18967-18984. [CrossRef]

31. Zhan, X.; Wang, D.; Bean, S.; Mo, X.; Sun, X.; Boyle, D. Ethanol production from supercritical-fluid-extrusion cooked sorghum. Ind. Crop. Prod. 2006, 23, 304-310. [CrossRef] 
32. Chinnadurai, K.; Muthukumarappan, K.; Julson, J.L. Enzymatic Hydrolysis of Corn Stover Pretreated in High Shear Bioreactor. In Proceedings of the ASABE Annual International Meeting, Providence, RI, USA, 29 June-2 July 2008. [CrossRef]

33. Lee, S.-H.; Teramoto, Y.; Endo, T. Enhancement of enzymatic accessibility by fibrillation of woody biomass using batch-type kneader with twin-screw elements. Bioresour. Technol. 2010, 101, 769-774. [CrossRef]

34. Karunanithy, C.; Muthukumarappan, K. Influence of extruder temperature and screw speed on pretreatment of corn stover while varying enzymes and their ratios. Appl. Biochem. Biotechnol. 2010, 162, 264-279. [CrossRef]

35. Yoo, J.; Alavi, S.; Vadlani, P.; Amanor-Boadu, V. Thermo-mechanical extrusion pretreatment for conversion of soybean hulls to fermentable sugars. Bioresour. Technol. 2011, 102, 7583-7590. [CrossRef]

36. Lamsal, B.; Yoo, J.; Brijwani, K.; Alavi, S. Extrusion as a thermo-mechanical pre-treatment for lignocellulosic ethanol. BiomassBioenergy 2010, 34, 1703-1710. [CrossRef]

37. Lee, S.-H.; Teramoto, Y.; Endo, T. Enzymatic saccharification of woody biomass micro/nanofibrillated by continuous extrusion process I-Effect of additives with cellulose affinity. Bioresour. Technol. 2009, 100, 275-279. [CrossRef]

38. Kang, K.E.; Han, M.; Moon, S.-K.; Kang, H.-W.; Kim, Y.; Cha, Y.-L.; Choi, G.-W. Optimization of alkali-extrusion pretreatment with twin-screw for bioethanol production from Miscanthus. Fuel 2013, 109, 520-526. [CrossRef]

39. Liu, C.; Van Der Heide, E.; Wang, H.; Li, B.; Yu, G.; Mu, X. Alkaline twin-screw extrusion pretreatment for fermentable sugar production. Biotechnol. Biofuels 2013, 6, 97. [CrossRef] [PubMed]

40. Karunanithy, C.; Muthukumarappan, K.; Gibbons, W. Sequential extrusion-microwave pretreatment of switchgrass and big bluestem. Bioresour. Technol. 2014, 153, 393-398. [CrossRef] [PubMed]

41. Agbor, V.B.; Cicek, N.; Sparling, R.; Berlin, A.; Levin, D.B. Biomass pretreatment: Fundamentals toward application. Biotechnol. Adv. 2011, 29, 675-685. [CrossRef] [PubMed]

42. Alvira, P.; Tomás-Pejó, E.; Ballesteros, M.; Negro, M. Pretreatment technologies for an efficient bioethanol production process based on enzymatic hydrolysis: A review. Bioresour. Technol. 2010, 101, 4851-4861. [CrossRef] [PubMed]

43. Hu, F.; Ragauskas, A.J. Pretreatment and lignocellulosic chemistry. BioEnergy Res. 2012, 5, 1043-1066. [CrossRef]

44. Esteghlalian, A.; Hashimoto, A.G.; Fenske, J.J.; Penner, M.H. Modeling and optimization of the dilute-sulfuric-acid pre-treatment of corn stover, poplar and switchgrass. Bioresour. Technol. 1997, 59, 129-136. [CrossRef]

45. Hu, G.; Heitmann, J.A.; Rojas, O.J. Feedstock pretreatment strategies for producing ethanol from wood, bark, and forest res-idues. BioResources 2008, 3, 270-294.

46. Ghaffar, S.H.; Fan, M. Lignin in straw and its applications as an adhesive. Int. J. Adhes. Adhes. 2014, 48, 92-101. [CrossRef]

47. Zhao, X.; Cheng, K.; Liu, D. Organosolv pretreatment of lignocellulosic biomass for enzymatic hydrolysis. Appl. Microbiol. Biotechnol. 2009, 82, 815-827. [CrossRef]

48. Duff, S.J.; Murray, W.D. Bioconversion of forest products industry waste cellulosics to fuel ethanol: A review. Bioresour. Technol. 1996, 55, 1-33. [CrossRef]

49. Ni, Y.; Van Heiningen, A. The swelling of pulp fibers derived from the ethanol-based organosolv process. Tappi J. 1997, 80, 211-213.

50. Zhu, L.; O'Dwyer, J.P.; Chang, V.S.; Granda, C.B.; Holtzapple, M.T. Structural features affecting biomass enzymatic digestibility. Bioresour. Technol. 2008, 99, 3817-3828. [CrossRef]

51. Sun, F.; Chen, H. Enhanced enzymatic hydrolysis of wheat straw by aqueous glycerol pretreatment. Bioresour. Technol. 2008, 99, 6156-6161. [CrossRef] [PubMed]

52. Guragain, Y.N.; De Coninck, J.; Husson, F.; Durand, A.; Rakshit, S.K. Comparison of some new pretreatment methods for second generation bioethanol production from wheat straw and water hyacinth. Bioresour. Technol. 2011, 102, 4416-4424. [CrossRef] [PubMed]

53. Bournay, L.; Casanave, D.; Delfort, B.; Hillion, G.; Chodorge, J. New heterogeneous process for biodiesel production: A way to improve the quality and the value of the crude glycerin produced by biodiesel plants. Catal. Today 2005, 106, 190-192. [CrossRef]

54. Hongzhang, C.; Liying, L. Unpolluted fractionation of wheat straw by steam explosion and ethanol extraction. Bioresour. Technol. 2007, 98, 666-676. [CrossRef] [PubMed]

55. Diner, B.A.; Fan, J. Organic Solvent Pretreatment of Biomass to Enhance Enzymatic Saccharification. U.S. Patent 2012/0270269 A1, 2012.

56. Li, Q.; He, Y.-C.; Xian, M.; Jun, G.; Xu, X.; Yang, J.-M.; Li, L.-Z. Improving enzymatic hydrolysis of wheat straw using ionic liquid 1-ethyl-3-methyl imidazolium diethyl phosphate pretreatment. Bioresour. Technol. 2009, 100, 3570-3575. [CrossRef] [PubMed]

57. Swatloski, R.P.; Spear, S.K.; Holbrey, J.D.; Rogers, R.D. Dissolution of cellose with ionic liquids. J. Am. Chem. Soc. 2002, 124, 4974-4975. [CrossRef]

58. Cheah, W.Y.; Sankaran, R.; Show, P.L.; Ibrahim, T.N.B.T.; Chew, K.W.; Culaba, A.; Chang, J.-S. Pretreatment methods for lignocellulosic biofuels production: Current advances, challenges and future prospects. Biofuel Res. J. 2020, 25, 1115-1127. [CrossRef]

59. Moniruzzaman, M.; Nakashima, K.; Kamiya, N.; Goto, M. Recent advances of enzymatic reactions in ionic liquids. Biochem. Eng. J. 2010, 48, 295-314. [CrossRef]

60. Zhao, H.; Jones, C.L.; Baker, G.A.; Xia, S.; Olubajo, O.; Person, V.N. Regenerating cellulose from ionic liquids for an accelerated enzymatic hydrolysis. J. Biotechnol. 2009, 139, 47-54. [CrossRef]

61. Hamelinck, C.N.; Van Hooijdonk, G.; Faaij, A.P. Ethanol from lignocellulosic biomass: Techno-economic performance in short-, middle- and long-term. Biomass Bioenergy 2005, 28, 384-410. [CrossRef] 
62. Li, J.; Gellerstedt, G. Improved lignin properties and reactivity by modifications in the autohydrolysis process of aspen wood. Ind. Crop. Prod. 2008, 27, 175-181. [CrossRef]

63. Teixeira, R.S.; Silva, A.S.; Moutta, R.O.; Ferreira-Leitão, V.S.; Barros, R.R.; Ferrara, M.A.; Bon, E.P. Biomass pretreatment: A critical choice for biomass utilization via biotechnological routes. BMC Proc. 2014, 8, O34. [CrossRef]

64. Taherzadeh, M.J.; Karimi, K. Pretreatment of lignocellulosic wastes to improve ethanol and biogas production: A review. Int. J. Mol. Sci. 2008, 9, 1621-1651. [CrossRef] [PubMed]

65. Sendich, E. (Newton); Laser, M.; Kim, S.; Alizadeh, H.; Laureano-Perez, L.; Dale, B.; Lynd, L. Recent process improvements for the ammonia fiber expansion (AFEX) process and resulting reductions in minimum ethanol selling price. Bioresour. Technol. 2008, 99, 8429-8435. [CrossRef] [PubMed]

66. Bals, B.; Teachworth, L.; Dale, B.; Balan, V. Extraction of proteins from switchgrass using aqueous ammonia within an integrated biorefinery. Appl. Biochem. Biotechnol. 2007, 143, 187-198. [CrossRef]

67. Zhao, X.; Zhang, L.; Liu, D. Biomass recalcitrance. Part II: Fundamentals of different pre-treatments to increase the enzymatic digestibility of lignocellulose. Biofuels Bioprod. Biorefining 2012, 6, 561-579. [CrossRef]

68. Wang, P.; Hu, X.; Cook, S.; Begonia, M.; Lee, K.S.; Hwang, H.-M. Effect of culture conditions on the production of ligninolytic enzymes by white rot fungi Phanerochaete chrysosporium (ATCC 20696) and separation of its lignin peroxidase. World J. Microbiol. Biotechnol. 2008, 24, 2205-2212. [CrossRef]

69. Irshad, M.; Asgher, M. Production and optimization of ligninolytic enzymes by white rot fungus Schizophyllum commune IBL-06 in solid state medium banana stalks. Afr. J. Biotechnol. 2013, 10, 18234-18242.

70. Hatakka, A. Lignin-modifying enzymes fungi: Production and role. FEMS Microbiol. Rev. 1994, 13, 125-135. [CrossRef]

71. Sluiter, A.; Hames, B.; Ruiz, R.; Scarlata, C.; Sluiter, J.; Templeton, D.; Crocker, D. Determination of Structural Carbohydrates and Lignin in Biomass; Terchnical report NREL/TP-510-42618; National Renewable Energy Laboratory (NREL): Golden, CO, USA, 2008.

72. Sluiter, A.; Ruiz, R.; Scarlata, C.; Sluiter, J.; Templeton, D. Determination of Extractives in Biomass; Terchnical report NREL/TP-51042619; National Renewable Energy Laboratory (NREL): Golden, CO, USA, 2008.

73. Del Río, J.C.; Rencoret, J.; Prinsen, P.; Martínez Ángel, T.; Ralph, J.; Gutiérrez, A. Structural Characterization of Wheat Straw Lignin as Revealed by Analytical Pyrolysis, 2D-NMR, and Reductive Cleavage Methods. J. Agric. Food Chem. 2012, 60, 5922-5935. [CrossRef] [PubMed]

74. Martínez Ángel, T.; Rencoret, J.; Marques, G.; Gutiérrez, A.; Ibarra, D.; Jiménez-Barbero, J.; Del Río, J.C. Monolignol acylation and lignin structure in some nonwoody plants: A 2D NMR study. Phytochemistry 2008, 69, 2831-2843. [CrossRef] [PubMed]

75. Guragain, Y.N.; Herrera, A.I.; Vadlani, P.V.; Prakash, O. Lignins of Bioenergy Crops: A Review. Nat. Prod. Commun. 2015, 10, 201-208. [CrossRef] [PubMed]

76. NGM. Next Generation Manufacturing Study Overview and Findings; The Manufacturing Performance Institute for the American Small Manufacturers Coalition: Washington, DC, USA, 2009.

77. Clark, J.H.; Farmer, T.J.; Herrero-Davila, L.; Sherwood, J. Circular economy design considerations for research and process development in the chemical sciences. Green Chem. 2016, 18, 3914-3934. [CrossRef]

78. Song, C.; Qiu, Y.; Liu, Q.; Ji, N.; Zhao, Y.; Kitamura, Y.; Hou, X. Process intensification of cellulosic ethanol production by waste heat integration. Chem. Eng. Res. Des. 2018, 132, 115-122. [CrossRef]

79. Nhien, L.C.; Long, N.V.D.; Lee, M. Novel heat-integrated and intensified biorefinery process for cellulosic ethanol production from lignocellulosic biomass. Energy Convers. Manag. 2017, 141, 367-377. [CrossRef]

80. Huang, R.; Su, R.; Qi, W.; He, Z. Bioconversion of lignocellulose into bioethanol: Process intensification and mechanism re-search BioEnergy Res. 2011, 4, 225-245. [CrossRef]

81. Yoon, L.W.; Ngoh, G.C.; Chua, A.S.M.; Patah, M.F.A.; Teoh, W.H. Process intensification of cellulase and bioethanol production from sugarcane bagasse via an integrated saccharification and fermentation process. Chem. Eng. Process. Process. Intensif. 2019, 142, 107528. [CrossRef]

82. Nagula, K.N.; Pandit, A.B. Process intensification of delignification and enzymatic hydrolysis of delignified cellulosic biomass using various process intensification techniques including cavitation. Bioresour. Technol. 2016, 213, 162-168. [CrossRef] [PubMed]

83. Gourdon, C.; Elgue, S.; Prat, L. What are the needs for process intensification? Oil Gas Sci. Technol. 2015, 70, 463-473. [CrossRef]

84. Beckham, G.T.; Johnson, C.W.; Karp, E.M.; Salvachau, D.; Vardon, D.R. Opportunities and challenges in biological lignin valorization. Curr. Opin. Biotech. 2016, 42, 40-53. [CrossRef]

85. Guragain, Y.N.; Chitta, D.; Karanjikar, M.; Vadlani, P.V. Appropriate lignocellulosic biomass processing strategies for efficient 2,3-butanediol production from biomass-derived sugars using Bacillus licheniformis DSM 8785. Food Bioprod. Process. 2017, 104, 147-158. [CrossRef]

86. Zhang, Y.; Yoshida, M.; Vadlani, P.V. Biosynthesis of d-lactic acid from lignocellulosic biomass. Biotechnol. Lett. 2018, 40, 1167-1179. [CrossRef] [PubMed]

87. Lee, J.-E.; Vadlani, P.V.; Guragain, Y.N.; San, K.-Y.; Min, D.-H. Production of free fatty acids from switchgrass using recombinant Escherichia coli. Biotechnol. Prog. 2018, 34, 91-98. [CrossRef] [PubMed] 